\title{
Historicising Silence: An Introduction to Australian Aboriginal Poetry
}

\author{
Ravichandra P Chittampalli*
}

\begin{abstract}
The paper looks at texts selected from the Anthology of Australian Aboriginal Literature edited by Anita Heiss and Peter Minter as well as poets chosen from the website Creative Spirits from Oodgeroo (Kath Walker) to Zelda Quakawoot to understand how gaze invents and reinvents people and their culture. The metaphor of the museum is used to question the Empire's attempt at erasing and archeologically reinventing ancient societies, while interrogating how dispossession leads to silencing of communities. The second part analytically delineates the evolution from a victim position to, consciousness raising, resistance, recovering and reconstruction of one's cultural heritage and voice. The third section of the paper conclusively argues how modern aboriginal poetry has attempted at non-choral, esoteric as well as representational identity formulations as a prelude to dehusking the valance of prejudice and civilisational arrogance, which continue to indent the First Citizen in cultural spaces.
\end{abstract}

Keywords: Aboriginal, Colonisation, Empire, Historicisation, Poetry, Silence

\section{Introduction}

A first encounter with the ancient world for most adults is when as a child, one is conducted through a Museum of Civilisation on a school trip or accompanied by an adult on a family vacation. The exhibits of the folk and their tradition behind warnings of "do not

* University of Mysore, Mysore, India; cpravichandra@gmail.com 
touch" and "silence please" at once create a schizoid experience in the mind of the observing child. The taboo zone beyond the guard rails, rope barrier or glass cased niche belongs forever to the limits of transactory experience. That world is othered in very firm juridico-ideological terms. Any attempt to breach is liable to be punished, in both ethical terms as well as in terms of a physical disapprobation such as being fined.

However, we need to go back in time for a bit. The very Museums of Civilisations across the world are testimonies not merely of modern archeological enterprise of "collecting the world" in one place but also testimonies to the underlying racial barbarism of the coloniser against the colonised, in refusing to allow root room for survival, let alone to flourish in a dignified manner. Thus the silent figures and artifacts from a lost civilisation intrude upon our consciousness today more as apologies or as exoticising the once alive and vibrant ways of living of a people or a civilisation. Thus the museums become modern physical domes of silence.

In Literature, the obverse happens. The writings of the ancient people or their progeny are acts of recovering the self, the space, the spirit, and the magic from beyond erasure. Thus we are here talking of two different processes of historicising: one an exhibit of man's shame and another, the dynamics of recovering pride. In fact the museums are already, always a testimony of continuing power of the centre over the periphery to which Denis Byrne alludes in her article. They are conscious constructs of power on display. The erased comity is brought back to the violence of gaze by museumising them:

the act of collection evaporates the evidence of their entitlement to land, since this evidence loses efficacy the moment it ceases to be in situ. In appropriating the discourse of heritage, Aborigines in places like NSW have reworked it into a discourse of land. (Byrne, 2003, p. 74)

We are reminded of Voss's monumental journey through the heart of Australia which ends up in his death. White seems to suggest that the Blacks in Australia can only 'repossess' their nation or their land if and when they can reject both the exploratory as well as the 
colonising attempt of the outsider. Here is a discourse of dispossession and nation construction, which as themes are beyond the present concern of this paper.

Dispossession imposes a silence on the people by refusing them any juridical rights to protest or represent. The result is to create reservations, which was done with great show of moral uprightness by the coloniser in the US, Canada and Australia. The human zoos were established not only to deny the rightful owners their inheritance of a land but also to permeate one's own claim to that land as a natural acquisition. The perpetrator becomes the benevolent master and in turn expects unalloyed loyalty and gratitude from the victim. This any way is an old story today much bandied about since the neo-colonial and post colonial discourses were begun to be employed.

What is of far more consequence is the distance we academicians are removed to from certain historical warps when we translate creative outpourings of a people into a newer and a differently structured form. I wish to draw in support a statement by Strehlow (1955):

The original Australian poets combined difficult rhythmic forms in an amazing series of variations. When a song was being chanted, it was not unusual for the singers to bring out its strong musical stresses in their chanting while tapping out simultaneously a different rhythm with their boomerangs. (p. 37)

When we translate into English such high drama, this intrinsically performative poetry, we have abandoned forever the "intoned verse", the excitingly rhythmic nature of such, to use again Strehlow's (1955) description, "composite form of art" (p. 37). The result is a pale, wordy almost always prosaic rendering in a weak language what has been partially absorbed. Yet, it is a translator's karma to translate.

The modern poems of the Original people of Australia appear to be a result of a remarkable change that has percolated not merely from dream time, myth making, and religious outpourings of a performative nature but also from a conscious effort to place 
themselves in a logocentric, sequential time, where duree is as important as duration. In this amalgamatory effort the voices grow politically aware, as the study of Erich Kolig (1995) reveals. It is this act of finding a political tenor, which was outside the pale of the ancient's thinking that modernises as well as empowers the contemporary experience of the original people of Australia. In almost all the poems that are to be discussed in this paper, it may be perceived that there is an attempt at prioritising the speaking voice as a historically wedged individual who is politically aware of his or her role as an interdictor. For, these voices are to be perceived as modern day religio-civil authorities of schooling the new generation. The poets, through their songs, attempt to flood the land inundated by "monotonous stupidity" (Hope's Australia), from Cairns to Perth a tradition and a sentiment that flows from myth seamlessly into history. The very act of writing poetry is to prioritise the individual experience, which same had no societal value in ancient wisdom. Individual experiences were only so many insignificant grains arranged on a cob in the ancient process of myth making- important collectively but by themselves of no significance.

\section{Analysis}

Oodgeroo (Kath Walker) sings an aubade of aboriginal poetry with her exhortation, filling the hearts of her people with optimism, asking them to slough the sense of racial inferiority, the historical reality of subjugation. She calls for not a passive amnesia but an active shrugging off of the past. She sees a different universe in front of her people when, in her own words:

When a juster justice

Grown wise and stronger

Points the bone no longer

At a darker race

In a poignant intonement in her "A Song of Hope" she asserts, "Night's nearly over". The word "nearly" which is cleverly interjected between the mischievously hopeful "Now" and the disarming assertion of finality in "over" at once belies the promise. The present is far from not being bleak. However, the poet would summon her people, "the dark freedom-lover" to dream anew. She 
promises a greater comradery as the much touted mateship of Australia was merely restricted to the white race, and the result shall be new myths and legends flowing from the teeming brain of her people. It is a "glad tomorrow" that she wishes her people. (Aboriginal culture - Arts - A Song of Hope, 2014)

Sharon Roebourne (2014) in her "All Walks Of Life" talks of her pride in being an aboriginal. The poem appears as though it is an answering call to Kath Walker's "A New Hope". There is a blustering tone that Roebourne employs, exhorting her audience not to waste precious time in mulling over the past. For her, it is not amnesia that will help but a deliberate turning away from all that ignominy and suffering of the past. It is therefore that she advocates

See plain the promise

Dark freedom-lover!

Night's nearly over

The essential romanticising of the aborigine as the "Dark freedomlover" somewhere is not unrelieved of the irony that he is yet not free. Jonathan Hill in his quiet and somber tone tells us how oblivious to the inherent violence that marks the birth of the modern nation that Australia is

I reflect on the cultures crushed

in the creation of this nation

and wonder how many Australians

know the extend(sic) of devastation.

These lines remind us of Hope's characterisation of the modern Australian as a "second-hand European". Contrast this with the elegiac encomiums that Hill pays in the poem "An Elder's Passing" (2010)

Only one source of solace soothes the growing grief as you descend into the Dreaming you are finally at peace.

The elder is the real Library of Australia, he is the real repository of all knowledge and culture. Our glib description of certain cultures 
as "Orature" needs to be reassessed in the light of such description as this. The world records the destruction of Assurbanipal's Library on the banks of Euphrates but who would keep track of the erasure of an archive of knowledge in the death of an aboriginal elder? When in 2008 Kevin Rudd formally apologised to the indigenous population for having "inflicted profound grief, suffering and loss", he did one of the most civilised gestures in contemporary politics. However it did not cut ice everywhere. The open season that the white Australian occasionally declared in the past on the indigenous population of Australia, which he did not then distinguish from the Kangaroos or the wallabies had scarred the history of Australia too deep to heal with a grand gesture. Though no one questions Rudd's or later Tony Abbot's convictions or honesty, the question is how much is enough? Samuel Mcclean (2000) in his poem "Burning Tree" which is quoted in full here indicates to something more than a pointer. To apologise is not enough:

In the words from a white Prime Minister, 'sorry'?

You think that justice has been served?

But where is my family tree the one that I deserved?

I lost mine in one generation, a generation where white man's justice was often curved.

We never asked for a 'sorry' in a politician's words, We asked for respect, a respect which needs to be earned.

But you will never get this off me, you lost it long ago.

The only time i will give you mine

Is when you find my grandma's name,

The name the white man burned!

What Mcclean is referring to here is the forcible separation of thousands of children from their families (BBC News, 2013). What was the fate of these children? Lyndon Lane (2011) from Goodooga, NSW in "Calling Me Home" provides us with an instance of the estrangement and the consequential sense of loss. It is no less poignant than Yeats' memory of Lake Isle of Innisfree or of the bells of Moscow in Paris for Anna Akhamatova 
To the banks of the Bokhara River running under the Richmond Bridge

You can hear the waters flow to the sound of an Elder's didge.

However, the speaker knows that he has a task to complete. He needs to educate himself. He needs to rein in his emotional needs and be practical. The poem voices a certain mature responsibility as a way out of the cultural impasse. Brevity is not always bad! In "Kinchela" one of the briefest of poems chosen for analysis here, we grow aware of the horrors of unjust treatment meted out to these segregated children. Paul Buttigieg, in "Kinchela (The Stolen Kids)" (2013) talks of how the kid is sodomised by the person incharge. The result is that the child attempts an escape. Instead of punishing the perpetrator, the hapless kid is dubbed a criminal by an unsympathetic juridical system:

We climbed through windows

We ran away

Criminals

Just

For being black and stolen

Travis Blair too in "Gumbaynggirr" echoes the sentiment.

The white man thought it was better

Destroying my family's sacred place

Removing all trees and making it a park

And calling it a "community space".

How can it be a community space?

When the families have left

The place lonely and uninviting,

It hurts inside my chest.

In spite of a carefully schematised action to erase the lore and the land of the dreamtimers, Blair's speaker gathers around him, the children of the present to pass on a legacy that is tenuously hanging on the mind boughs and lips of a very few. He will tell them the stories of the past and historicise the silences. That is the only way to cauterise the wound in the heart. Very interestingly Erich Kolig in an essay on the sense of history among the original 
people of Australia comments on the impact of Western education on the younger generation. He recognised the need to "synthesise" and "cognitively harmonise the western historical apperception with the ancient "myth consciousness" (Kolig, 1995, p. 50) in Judith Wright's much earlier poem "Bora Ring"

The song is gone; the dance

is secret with the dancers in the earth,

the ritual useless, and the tribal story

lost in an alien tale.

In her characteristic highly emotive style Judith Wright line after line in her short three stanza poem makes us halt at every word and hang our head in shame at our perfidy.

This act of spreading roots appears to have yielded some results in an acute sense of mateship that is felt among the aboriginals across Australia. The oneness and the sense of belonging that permeates among the aboriginal people is romanticised in a poem that reminds one of the bush songs of Australia in "I Got 'Lations'" by John M Wenitong (2014)

They'll meet you and greet you and give you bed

No matter in Auss where you find your head

There's always room to rest said head

On floor on carpet a car or shed and even in a double bed

This sense of belonging is an essential stage in the act of recovering a tradition and reconstructing a workable past. Out of the ruins will then emerge the new structure. All new songs and poems will then be floral offerings to the old bones. And then one may be like Judith Wright in "Bullocky" be able to luxuriously utter:

$\mathrm{O}$ vine, grow close upon that bone and hold it with your rooted hand.

But such a vision is a long time coming. For now, it is Jack Davis' (1978) demand for recognising first the horrendous crimes committed against the aboriginal in his poem "Aboriginal Australia" that needs to be addressed. The white man is accused of prevarication: 
Now you primly say you' re justified,

And sing of a nation's glory,

But I think of a people crucified -

The real Australian story.

Jeanine Leane (2010) in her explosive poem "Dark Secrets" shames us at the wrong meted out to the aborigines by the white Australians. The nursery rhyme that jeeringly 'others' the native Australian as the result of a divine amnesia and the life behind the fence are portraits that bring out in straight but brilliant contrasts the double face of Australia. In the first of the contrasts, the poet deliberately reproduces a clichéd picture of the children of the white Australian as "golden haired, angel-faced/happy white children". In contrast the children of the black race appear as victims. They are dehumanised through the children's rhyme and then incarcerated. The children are a part of the forgotten race:

They keep us locked away like dark secrets.

Never hearing our cries,

never seeing our misery,

never feeling our hunger

Australia, their home is now turned into a prison. It was a land of god's plenty. This is perhaps because

this whole country

was one big kitchen

where the pantry was never empty.

The sense of belonging, that sense of being rich, of not wanting for anything are all at once destroyed by the incursion of the White race. It must be borne in mind that for the Aborigine the spacetime continuum is very sacred and is always inextricably interwoven with his landscape. Nancy D. Munn argues this fact very cogently, "Australian Aboriginal spatial interdictions that are pervasive wherever Aborigine still treat the land in everyday life as the ancestrally derived locus of Aboriginal law" (Munn, 1996, p. 447). Anyone who had studied the manner in which Australia was settled by the Britisher will know for sure that it was no love for Australia that made him settle down there. Richard G. Kennedy succinctly sums up the history of one of the most unconscionable attitude towards a new land that Australia was burdened with 
when he almost in a Hopean despair says: "Mother earth is wounded and left in tatters". For Hope, Australia is a country where "her five cities like five teaming sore drain her from Perth to Cairns." The Native Australian finds himself a stranger in his own land. Rachel Davidge's (2006) persona in "Displaced" asks the question, "where to go treading on now foreign land?" For Davidge, the aborigine is an individual who has been robbed of his spirit, who has to grow incognito, with nowhere to go. Lost utterly, troubled and unheeded. Landon Punch's (2011) rather wry narrative "From Past to Present" not only talks of the comfortable lives of the contemporary aborigine in relation to what his ancestors had to go through but also talks of the criminalisation of him under the new laws, the manner in which the aboriginal was short changed in Australia. The poem though has little finesse or art to it, still grows evocative in its simple statements, and the use of the laconic tone. K L Burns (2014), in "Galiny Bulmba" (Come to my place) talks about how the land is not something that is in a casual relation with the aborigine. It has a spiritual connection. It is not something that is there to be exploited. For it is an act of dreaming, a "second skin" as it were. Burns's singularly spiritual outpouring, in an exemplary manner recounts how the aborigine and Australia were in a symbiotic relationship and still are in spite of what history has perpetrated. I would read Burns in conjunction with Hope's Australia, or McAuley's (1964) in order to bring to relief the polar difference in the perspective of the coloniser and the original inhabitant. For a romantic James McAuley (1964), a positive relationship with Australia can only be established by calling it "Quiro's vision", but for Burns, Australia is

My land is a secret dreaming

My home is a sacred blessing

And all the stories were handed down

In the night by the firelight, gather around.

This dream has to be secret because it is esoteric to each dreamer therefore it is not something that one can easily adopt like McAuley does in "Australia Felix". There is an umbilical relationship that the speaking voice enjoys with the land. That is the reason why it is sacred. This assertion takes us far, far away from the envisioning of the Australian as a "wandering island" by Hope. The speaker is 
surrounded by the mystery and the wonder of living; it is no mere "land of similes" as McAuley attempts to exoticise Australia in "Australia Felix". Vincent Buckley (1954) in "Australa" calls it the "cheated land" and accuses it of harbouring rancour. But in direct contrast you have Burns who celebrates a great symbiotic relationship with Australia:

The wind told me who I was

The law-giving wedge-tailed eagle

Made me take sacred oaths to protect my old people.

It is not just a sense of belonging but a proud assertion of having a mission that takes us by surprise as we arrive at Burns Poem. The sad tunes of the earlier poets now make way for a daring, purposeful voice. Australia summons her children:

Ngayu Galing Bulmba Nyundu Yinan

(Come to my place because you will be welcome).

\section{Conclusion}

From the preceding examination, it grows apparent that the modern aboriginal world is no more apodictical, which it once was when it was enmeshed in dreamtime. The vast change that has come over it through an erosion of its sociology, its ethical and imaginary universe has catapulted it into a world in which a new explanation has to be found before the valance of prejudice and civilisational arrogance can be lifted. From Oodgeroo to recent times, the aboriginal voices have seriously attempted to do precisely this. The stolen generation needs to return to the Bora Ring before much can be achieved. However, the dynamics of history is not such that people who have been forcefully caesareaned from the womb of their culture can easily return to the all nurturing, self-sufficiency of the womb. It is also not known if there is ever a return to the womb. The attempt by generation of traumatised populations has been to recover the path, at least symbolically. A. D. Hope very sagely utters at the end of his poem Beyond Khancoban (1981), that "Man has been made by all that has made the history of man". The poet, aboriginal or otherwise can only like Yeats today summon his soul to "the winding ancient 
stair" ("A dialogue of self and soul"). Yet Australia rightly belongs to its people. Aaron Richardson's (2014) "Australian" is the great new space, the new world where a new welcome is made to the visitor, who now is invited to unshod and walk bare torso upon the sands of time and share the corroborree with the "owners of the land"

I come from Australia

where we do not wear a shirt

We walk around bare footed, dancing in the dirt.

And we make them feel welcome, the people overseas

To our mother country

we make them feel at ease.

Because this land belongs to us and it always will

So remember that along the track or even better still

Take off your shoe and your shirt as you walk upon the sand,

And come and sit down in the dirt with the owners of this landi.

\section{References}

BBC News. (September 26, 2013). New Australia PM Tony Abbott forms indigenous council. Retrieved from https:// www.bbc.com/ news/ world-asia-24280043

Byrne, D. (2003). The ethos of return: Erasure and reinstatement of aboriginal visibility in the Australian historical landscape. Historical Archaeology, 37(1), 73-86. Retrieved from http:// www.jstor.org/ stable/25617044 
Kolig, E. (1995). A sense of History and the reconstitution of cosmology in Australian Aboriginal Society. The case of myth versus History. Anthropos, 90(1/3), 49-67. Retrieved from http:// www.jstor.org/ stable/40463104

Munn, N. D. (1996). Excluded spaces: The figure in the Australian Aboriginal landscape. Critical Inquiry, 22(3), 446-465. Retrieved from http://www.jstor.org/stable/1344017. Accessed: 28/09/2014 00:40

Strehlow, T. G. H. (1955). Australian aboriginal songs. Journal of the International Folk Music Council, 7, 37-40. Retrieved from http://www.jstor.org/stable/834-535 . Accessed: 27/09/2014 21:45

i "The archaeological and ethnological work of collection had a context in the great enterprise of "collecting the world" that was critical to the West's ability to know, exploit, and dominate the non-West during the Age of Imperialism." 